\title{
ХИНОКСАЛИН КАК ПЕРСПЕКТИВНЫЙ СКАФФОЛД ДЛЯ РАЗРАБОТКИ ПРЕПАРАТОВ С ПСИХОТРОПНОЙ АКТИВНОСТЬЮ
}

\author{
М.О. Скрипка', Р.И. Мусаев', М.В. Мирошников ${ }^{1,2}$
}

${ }^{1}$ Кафедра фармакологии и биоинформатики, Федеральное государственное бюджетное образовательное учреждение высшего образования

«Волгоградский государственный медицинский университет» Минздрава России, 400131, Россия, г. Волгоград, площадь Павших Борцов, д. 1.

2Лаборатория экспериментальной фармакологии, Государственное бюджетное учреждение «Волгоградский медицинский научный центр» 400131, Россия, г. Волгоград, площадь Павших Борцов, д. 1.

DOI: 10.19163/MedChemRussia2021-2021-513_E-mail: rete.mirabile.renis@gmail.com

На моделях «Приподнятого крестообразного лабиринта» и «Темной/светлой камеры» [1] было изучено 10 новых производных хиноксалина, синтезированных НИИ ФОХ ЮФУ г. Ростов-на-Дону в.н.с. Л.Н. Диваевой, Т.А. Кузьменко, А.С. Морковником. В качестве препарата сравнения выступил диазепам в скрининговой дозе 1 мг/кг [2], исследуемые соединения изучались в эквимолярных диазепаму дозах. В результате исследования выявлено, что время, проведенное мышами в светлых отсеках установок под влиянием 4 наиболее активных субстанций, было сопоставимо с диазепамом. Отмечено, что присутствие 4-нитрофенильного или 3,4-дихлорфенильного остатка в положении 3 коровой структуры соединений ведет к существенному повышению анксиолитической активности, в то время как наличие в том же положении 4-бромфенила или метильной группы негативно влияло на уровень искомой активности. Таким образом, среди новых производных хиноксалина выделены субстанции, перспективные с точки зрения дальнейшего углубленного изучения противотревожной активности.<smiles>CNCCc1cc(OC)c(OC)cc1Cc1nc2ccccc2nc1-c1ccccc1</smiles>

Puc. 1. 2-\{4,5-диметокси-2-[(3-фенилхиноксалин-2-ил) метил]фенил\}-N-метилэтан-1 амин гидробромид, одно из наиболее активных среди изучаемых соединений.

Исследование выполнено при финансовой поддержке РФФИ в рамках научного проекта № 20-015-00164.

\section{Литература}

[1] Таран А.С., Мальцев Д.В., Яковлев Д.С. и др. Изучение анксиолитической активности в ряду новых производных диазепинобензимидазола на установке «Приподнятый крестообразный лабиринт» // Волгоградский научно-медицинский журнал. - 2017. № 1 (53). - C. 24-26.

[2] Maltsev, D. V., Spasov, A. A., Yakovlev, D. S. et al. Searching for new anxiolytic agents among derivatives of 11-dialkylaminoethyl-2, 3, 4, 5-tetrahydrodiazepino[1, 2-a]benzimidazole. Eur. J. Pharmaceutical Sci., 2021, 161, 105792. 